\title{
The Protonmotive Force in Pseudomonas aeruginosa and its Relationship to Exoprotease Production
}

\author{
By MICHAEL A. WHOOLEY AND AIDEN J. MCLOUGHLIN* \\ Department of Industrial Microbiology, University College, Dublin 4, Ireland
}

(Received 7 May 1982; revised 13 July 1982)

\begin{abstract}
In Pseudomonas aeruginosa ATCC 10145 a negative correlation was observed between the protonmotive force $(\Delta \mathrm{P})$ and the amount of exoprotease produced, with a decrease in $\Delta \mathrm{P}$ resulting in an increase in exoprotease. The two components of $\Delta \mathrm{P}$, the transmembrane $\mathrm{pH}$ gradient $(\Delta \mathrm{pH})$ and the membrane potential $(\Delta \psi)$ were examined independently and it was observed that $\Delta \psi$ varied very little under the conditions which influenced the activities of exoprotease. However, a positive correlation existed between $\mathrm{pH}$ and exoprotease production although the intracellular $\mathrm{pH}$ varied very little with either changes in growth rate or changes in extracellular $\mathrm{pH}$. It was observed that with a decrease in growth rate, $\Delta \mathrm{pH}$ became more alkaline and increased exoprotease activities were recorded. Furthermore, an increase in extracellular $\mathrm{pH}$ to give an artificial alteration in $\Delta \mathrm{pH}$, and, consequently, a decrease in $\Delta \mathrm{P}$, increased exoprotease production, thus confirming the importance of $\Delta \mathrm{pH}$ in exoprotease production.
\end{abstract}

\section{INTRODUCTION}

Previous investigations in this laboratory into the regulation of exoprotease production by Pseudomonas aeruginosa indicated the importance of the energy status of the cells. Exoprotease production was found to be repressed in energy-sufficient cells and derepressed in energydeficient cells (Whooley et al., 1983); regulation of exoprotease production by another Gramnegative organism, Vibrio sp., appeared to be under a similar control (Wiersma, 1978). In order to determine the exact nature of this energy-linked regulation of exoprotease production, the energy generating systems of $P$. aeruginosa were examined.

Pseudomonas aeruginosa is a strict aerobe (Stanier et al., 1966) and is therefore mainly dependent on respiratory electron transport for energy generation. This energy is in the form of an electrochemical potential for protons across the membrane generated by protontranslocating pumps. The energy in this electrochemical potential is utilized as a driving force for several membrane-related processes such as oxidative phosphorylation (Wilson et al., 1976; Maloney, 1977; Tsuchiya, 1977), nutrient transport (for reviews see Harold, 1974; Dills et al., 1980) and motility (Goulbourne \& Greenberg, 1980; Shioi et al., 1980).

In this paper extracellular $\mathrm{pH}$ (i.e. the $\mathrm{pH}$ of the culture) and growth rate were examined for their effects on the protonmotive force (and its two components) and exoprotease production.

\section{METHODS}

Organism and growth. Pseudomonas aeruginosa ATCC 10145 was maintained and grown as described previously (Whooley et al., 1982).

Enzyme assay. Protease activity was assayed as described in the previous paper (Whooley et al., 1983). Units of activity $(U)$ were calculated from a standard curve and are expressed as $\mu \mathrm{g}$ tyrosine released from casein per $\mathrm{ml}$ of cell-free supernatant per hour at $30^{\circ} \mathrm{C}$.

Abbreviations: $\mathrm{pH}_{\mathrm{ex}}$, extracellular $\mathrm{pH}$ (i.e. $\mathrm{pH}$ of medium or culture); $\mathrm{pH}_{\mathrm{in}}$, intracellular $\mathrm{pH} ; \Delta \mathrm{pH}$, transmembrane $\mathrm{pH}$ gradient $\left(\Delta \mathrm{pH}=\mathrm{pH}_{\mathrm{ir}}-\mathrm{pH}_{\mathrm{ex}}\right) ; \Delta \psi$, membrane potential; $\Delta \mathrm{P}$, protonmotive force $(\Delta \mathrm{P}=\Delta \psi-59 \Delta \mathrm{pH})$. 
Measurement of intracellular volume. The intracellular volume was determined by a modification of the method of Collins \& Hamilton (1976). To triplicate $3 \mathrm{ml}$ samples of culture $0 \cdot 1 \mathrm{ml}$ (hydroxy $\left[{ }^{14} \mathrm{C}\right]$ methyl)inulin $(11 \cdot 3 \mathrm{mCi}$ $\mathrm{mmol}^{-1}, 418 \mathrm{MBq} \mathrm{mmol}{ }^{-1}$ ), dissolved in distilled water, was added to give a final concentration of $73.75 \mu \mathrm{M}$ and $0.1 \mathrm{ml}^{3} \mathrm{H}_{2} \mathrm{O}$, to give a final concentration of $15 \mu \mathrm{Ci} \mathrm{ml}^{-1}\left(555 \mathrm{KBq} \mathrm{ml}^{-1}\right)$. Samples were incubated on a roller drum at $27^{\circ} \mathrm{C}$ for $20 \mathrm{~min}$ and then centrifuged at $13000 \mathrm{~g}$ for $15 \mathrm{~min}$ and the supernatants poured off. The insides of the tubes containing the pellets were swabbed dry with cotton buds to remove any adhering droplets of the cellfree supernatant (Kashket \& Wong, 1969) and the pellets were resuspended in $2 \mathrm{ml}$ water. The resuspended pellet $(0.5 \mathrm{ml})$ was added to $5 \mathrm{ml}$ of a scintillation fluid containing: PPO, $4 \mathrm{~g}$; POPOP, $100 \mathrm{mg}$; Triton X-100, $333 \mathrm{ml}$; toluene, $667 \mathrm{ml}$. Cell-free supernatant $(0 \cdot 1 \mathrm{ml})$ along with $0.4 \mathrm{ml}$ water was added to another vial containing $5 \mathrm{ml}$ of the toluene/Triton scintillation fluid. The vials were stored at ambient temperature for $12 \mathrm{~h}$, which allowed the establishment of a stable gel with the radioactivity evenly distributed, and were then counted on a Packard model 2002 Tri-Carb liquid scintillation spectrometer.

Since hydroxymethyl inulin does not enter the cells, the ${ }^{14} \mathrm{C}$ activity represents the extracellular water trapped in the pellet, and the ${ }^{3} \mathrm{H}$ activity represents the intracellular plus the extracellular water. The intracellular volume $\left(V_{i}\right)$ was calculated from the equation

$$
\mathrm{V}_{\mathrm{i}}=\left({ }^{3} \mathrm{H} \text { in pellet } /{ }^{3} \mathrm{H} \text { in supernatant }\right)-\left({ }^{14} \mathrm{C} \text { in pellet } /{ }^{14} \mathrm{C} \text { in supernatant }\right)
$$

Measurement of transmembrane $p H$ gradient $(\triangle p H)$ and intracellular $p H\left(p H_{i n}\right) . \mathrm{pH}$ was determined from the distribution of methylamine hydrochloride (Rottenberg et al., 1972). A sample was taken from the culture vessel and to triplicate $3 \mathrm{ml}$ samples, $0.1 \mathrm{ml}\left[{ }^{14} \mathrm{C}\right]$ methylamine hydrochloride, $\left(40.4 \mathrm{mCi} \mathrm{mmol}^{-1}, 1.49 \mathrm{GBq} \mathrm{mmol}^{-1}\right)$ dissolved in distilled water was added to give a final concentration of $20.625 \mu \mathrm{M}$. The tubes were placed on a roller drum at $27^{\circ} \mathrm{C}$ for $20 \mathrm{~min}$ (to allow equilibration of methylamine across the membrane) and were then centrifuged at $13000 \mathrm{~g}$ for $15 \mathrm{~min}$ and the supernatants poured off. Samples of the resuspended pellet and the supernatant were assayed for radioactivity as described for measurement of intracellular volume.

The value of $\Delta \mathrm{pH}$ (inside acidic) was calculated from $\log \left(\right.$ methylamine $_{\text {in }} /$ methylamine $\left._{\text {out }}\right)$. The values for $\left(\right.$ methylamine $_{\text {in }}$ ) were corrected using the calculated value for intracellular volume in order to exclude the counts due to methylamine in the extracellular pellet water.

Intracellular $\mathrm{pH}$ was taken as extracellular $\mathrm{pH}$ minus $\Delta \mathrm{pH}$, where extracellular $\mathrm{pH}$ was the $\mathrm{pH}$ of the culture.

Measurement of membrane potential $(\Lambda \psi)$. The membrane potential of $P$. aeruginos $a$ cells was determined using $14 \cdot 125 \mu \mathrm{M}$-potassium $\left[{ }^{14} \mathrm{C}\right]$ thiocyanate $\left(59 \mathrm{mCi} \mathrm{mmol}^{-1}, 2 \cdot 18 \mathrm{GBq} \mathrm{mmol}^{-1}\right)$. The procedure followed was the same as that used in intracellular $\mathrm{pH}$ determinations. The protonmotive force was calculated from the equation

$$
\Delta \mathrm{P}=\Delta \psi-59 \Delta \mathrm{pH}
$$

Chemicals. Antifoam A, PPO and POPOP were obtained from Sigma. [ $\left.{ }^{14} \mathrm{C}\right]$ Methylamine hydrochloride, (hydroxy $\left[{ }^{14} \mathrm{C}\right]$ methyl)inulin, potassium $\left[{ }^{14} \mathrm{C}\right]$ thiocyanate and ${ }^{3} \mathrm{H}_{2} \mathrm{O}$ were obtained from Amersham. All other chemicals used were BDH AnalaR grade.

\section{RESULTS}

\section{Extracellular $\mathrm{pH}$ and exoprotease production}

Previous investigations of exoprotease production in a medium containing $1 \%(\mathrm{w} / \mathrm{v})$ Casamino acids as the sole source of carbon and energy (Whooley et al., 1983) revealed that maximum production occurred in the decelerating phase of growth and continuous culture studies revealed that as growth rate decreased, exoprotease production increased linearly. However, it was also noted that the $\mathrm{pH}$ of the medium, the extracellular $\mathrm{pH}\left(\mathrm{pH}_{\mathrm{ex}}\right)$, increased with decreasing growth rate, paralleling the effect of growth rate on exoprotease production (Fig. 1).

\section{Intracellular $p H, \triangle p H$ and $\Lambda \psi$}

The influence this variation in extracellular $\mathrm{pH}$ had on the internal environment of the cell was examined. Before measuring the intracellular $\mathrm{pH}$, the postulate that the cell membrane was much more permeable to the undissociated form of the base had to be tested. This was accomplished using the method of Harold et al. (1970). Osmotically sensitive cells of the organism were prepared by the Spizizen (1957) method and were incubated in $0.5 \mathrm{M}$-sucrose solutions at different $\mathrm{pH}$ values. Some of these cells were also added to $0.5 \mathrm{~m}$ unlabelled methylamine hydrochloride at $\mathrm{pH}$ values of 11.0 and 8.0 (i.e. above and below its $\mathrm{p} K$ value of 10.6). 


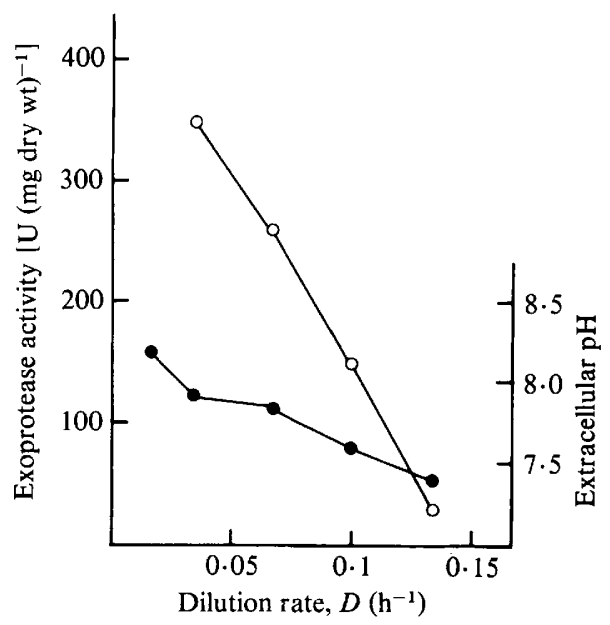

Fig. 1. The influence of growth rate on extracellular $\mathrm{pH}$ and exoprotease production by $P$. aeruginosa in continuous culture at $27^{\circ} \mathrm{C}$ under conditions of carbon-limitation (Casamino acids). Exoprotease activity $(\mathrm{O})$, extracellular $\mathrm{pH}(\mathbf{O})$

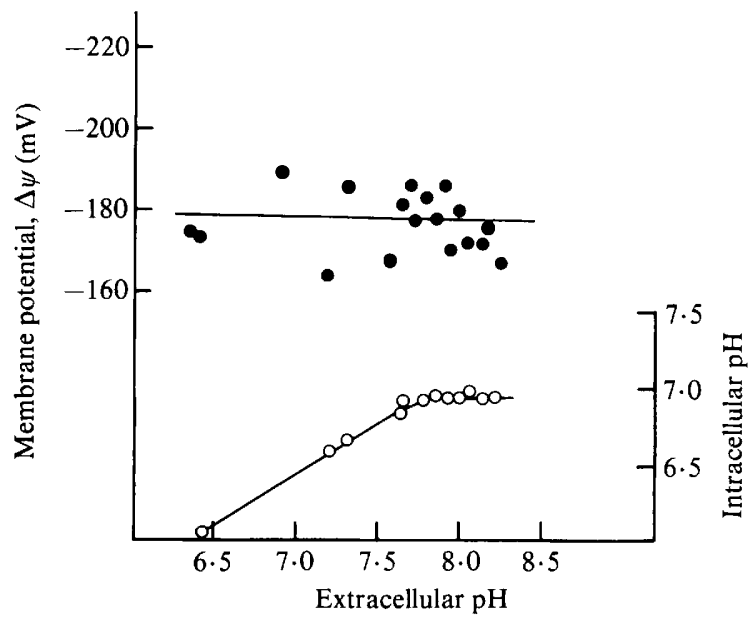

Fig. 2. The effect of extracellular $\mathrm{pH}$ on intracellular $\mathrm{pH}(\mathrm{O})$ and membrane potential $(\bigcirc)$ of $P$. aeruginosa in continuous culture at $27^{\circ} \mathrm{C}$ under conditions of carbon limitation (Casamino acids). Dilution rate was $0 \cdot 1 \mathrm{~h}^{-1}$. Values of $\mathrm{pH}$ were controlled by the automatic addition of $\mathrm{NaOH}$ or $\mathrm{HCl}$.

After $10 \mathrm{~min}$ the absorbance at $650 \mathrm{~nm}$ was measured and a decrease was taken to be indicative of lysis. Methylamine hydrochloride was found to stabilize these cells at $\mathrm{pH} 8 \cdot 0$. Above its $\mathrm{p} K$ value (i.e. at $\mathrm{pH} 11.0$ ) methylamine hydrochloride caused lysis.

When intracellular $\mathrm{pH}$ values of cells growing at different controlled extracellular $\mathrm{pH}$ values were determined, intracellular pH was found to be more acidic at all the values studied (Fig. 2). The intracellular $\mathrm{pH}$ increased with increasing extracellular $\mathrm{pH}$ up to an intracellular $\mathrm{pH}$ value of approximately $7 \cdot 0$ (which corresponded to an extracellular value of approximately $7 \cdot 5$ ), and thereafter any further increase in extracellular $\mathrm{pH}$ resulted in very little change in intracellular $\mathrm{pH}$, suggesting a buffering effect of the cytoplasm.

The membrane potential was found to be negative inside. No relationship was apparent between membrane potential and extracellular $\mathrm{pH}$ and, indeed, over the range of $\mathrm{pH}$ values studied, the $\Delta \psi$ was found to remain within -165 to $-190 \mathrm{mV}$ (Fig. 2). 


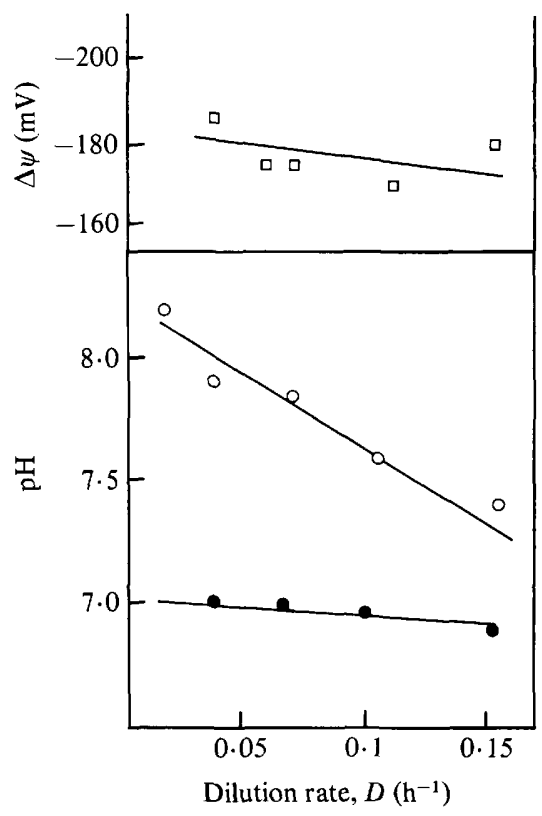

Fig. 3. The influence of growth rate on extracellular $\mathrm{pH}(\mathrm{O})$, intracellular $\mathrm{pH}(\mathrm{O})$ and membrane potential $(\square)$ of $P$. aeruginosa in continuous culture at $27^{\circ} \mathrm{C}$ under conditions of carbon limitation.

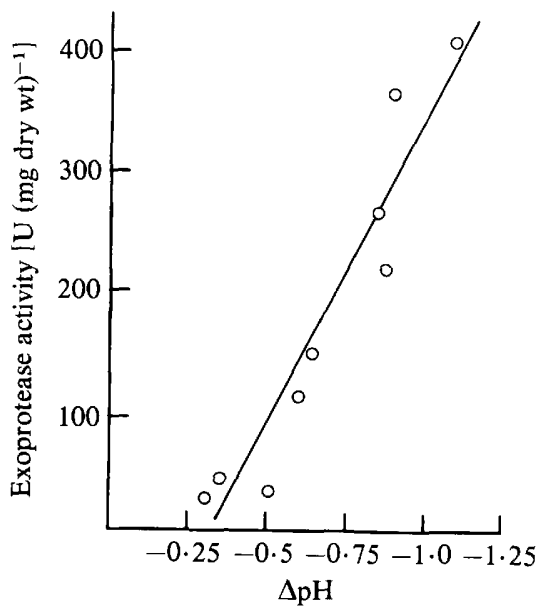

Fig. 4. Correlation between the transmembrane $\mathrm{pH}$ gradient $(\Delta \mathrm{pH})$ and the production of exoprotease by $P$. aeruginos $a$ under controlled $\mathrm{pH}$ conditions.

Intracellular $\mathrm{pH}$ was found to be unaffected by growth rate, remaining relatively constant at approximately pH 7.0 (Fig. 3) confirming the buffering effect of the cytoplasm suggested in Fig. 2. However, the magnitude of the transmembrane $\mathrm{pH}$ gradient was found to increase (becoming more acidic internally relative to external $\mathrm{pH}$ ), with decreasing growth rate. The intracellular $\mathrm{pH}$ was only determined at those growth rates where exoprotease was produced i.e. less than $0 \cdot 15 \mathrm{~h}^{-1}$. At all these growth rates $\mathrm{pH}_{\mathrm{in}}<\mathrm{pH}_{\mathrm{ex}}$, therefore, the $\Delta \mathrm{pH}$ had a negative value.

The value of the membrane potential also appeared to be relatively unaffected by growth rate over the range examined, with only a difference of approximately $10 \mathrm{mV}$ between the values at growth rates of $0.02 \mathrm{~h}^{-1}$ and $0.15 \mathrm{~h}^{-1}$ (Fig. 3).

Since it was shown in Fig. 3 that $\Delta \mathrm{pH}$ decreased (i.e., became less acidic) with increasing 


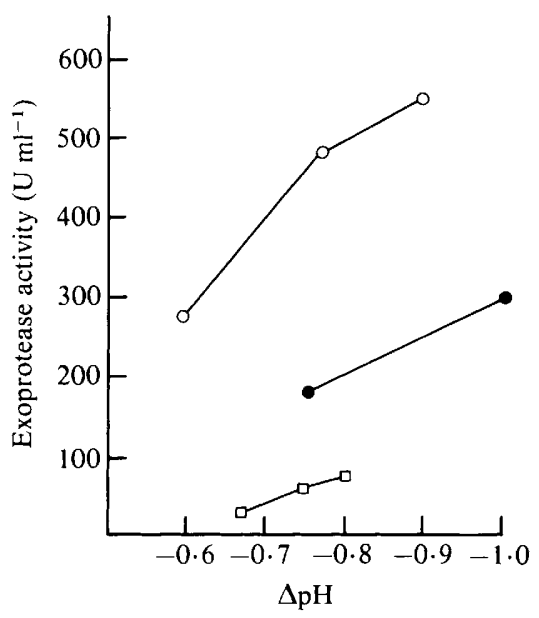

Fig. 5. The effect of the magnitude of the transmembrane $\mathrm{pH}$ gradient on exoprotease production by $P$. aeruginosa at different controlled growth rates in continuous culture at $27^{\circ} \mathrm{C}$ under conditions of carbon limitation. $D\left(\mathrm{~h}^{-1}\right)=0.033(\mathrm{O}), 0 \cdot 1(\bigcirc), 0.133(\square)$.

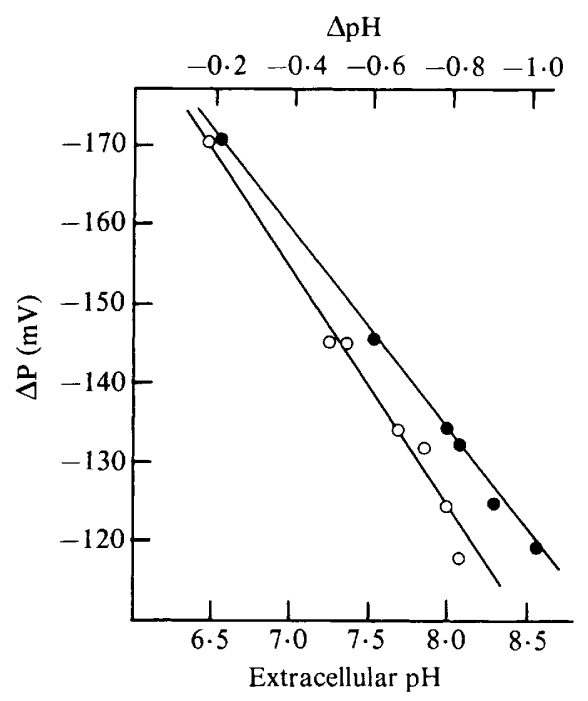

Fig. 6. The effect of extracellular $\mathrm{pH}$ on protonmotive force $(O)$ and the relationship between transmembrane $\mathrm{pH}$ gradient $(O)$ and protonmotive force of $P$. aeruginosa cells in continuous culture at $27^{\circ} \mathrm{C}$ under conditions of carbon limitation $\left(D=0 \cdot 1 \mathrm{~h}^{-1}\right)$.

growth rates (in a similar fashion to extracellular $\mathrm{pH}$ ) and that exoprotease production increased with increasing growth rate (Fig. 1), the relationship between $\Delta \mathrm{pH}$ and exoprotease production was investigated. Figure 4 demonstrates that exoprotease production increased with increasing (negative value) $\Delta \mathrm{pH}$. Therefore, it is evident that there is a relationship between exoprotease production and $\Delta \mathrm{pH}$.

To determine if the $\Delta \mathrm{pH}$ effect on exoprotease production is independent of growth rate, the latter was kept constant at three different values $\left(0.033,0.1\right.$ and $\left.0.133 \mathrm{~h}^{-1}\right)$ and a $\Delta \mathrm{pH}$ was imposed by controlling the extracellular pH using a $0.5 \mathrm{M}-\mathrm{NaOH}$ or $\mathrm{HCl}$. The $\mathrm{pH}$ range examined was between 7.25 and 8.0 since it was over this range that maximum exoprotease production occurred (Fig. 1). Exoprotease production increased with increasing $\Delta \mathrm{pH}$ at all the growth rates (Fig. 5). The effect of $\Delta \mathrm{pH}$ on exoprotease production was more pronounced as the growth rate decreased. Therefore, it appears that an increase in $\Delta \mathrm{pH}$ (negative value) enables 


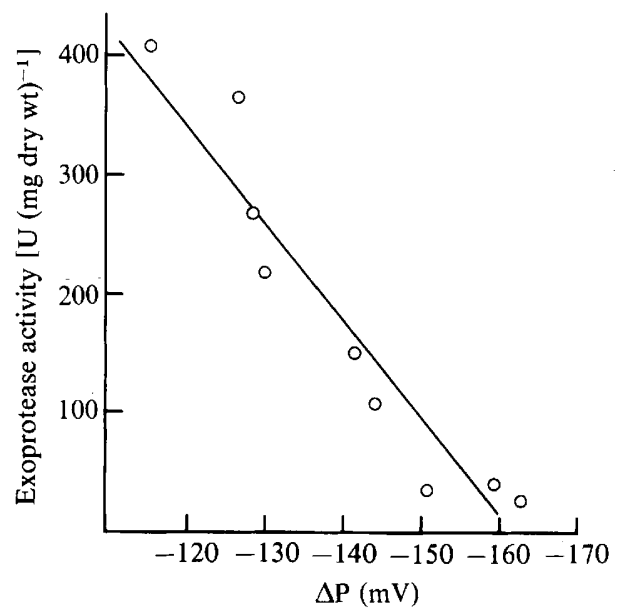

Fig. 7. The influence of the magnitude of the protonmotive force on the production of exoprotease by $P$. aeruginosa.

increased exoprotease production. Also, since the rate of exoprotease production per change in $\Delta \mathrm{pH}$ increased with increasing growth rate, it is evident that both $\Delta \mathrm{pH}$ and growth rate exert independent effects on exoprotease production.

\section{The protonmotive force}

The protonmotive force was calculated from the measured values of $\Delta \psi$ and $\Delta \mathrm{pH}$. Because the membrane potential remained constant within limits $(-165$ to $-190 \mathrm{mV})$ irrespective of extracellular $\mathrm{pH}$ or growth rate, the protonmotive force decreased with increasing extracellular pH (Fig. 6). Indeed, because of the constancy of the membrane potential under the conditions studied, the protonmotive force was directly dependent on the $\Delta \mathrm{pH}$. It was found that as the $\Delta \mathrm{pH}$ increased (i.e. became more acidic), the protonmotive force decreased.

The values of the protonmotive force for the $\Delta \mathrm{pH}$ values of Fig. 5 were calculated and plotted against the corresponding exoprotease levels and it was found that as the protonmotive force decreased, exoprotease production increased in a linear fashion (Fig. 7).

\section{DISCUSSION}

Most of the determinations in bacteria of the protonmotive force and its two components, $\Delta \mathrm{pH}$ and $\Delta \psi$, have been carried out on 'resting' cell suspensions (usually exponential phase cells resuspended in buffer) and on spheroplasts and vesicles (for reviews see Rottenberg, 1975; Maloney et al., 1975). Recently, however, some investigations of $\Delta \mathrm{P}$ in growing cells have been reported (Kashket, 1981 $a, b$ ). In our investigation, growing cells were also used and, indeed, using continuous culture the $\Delta \mathrm{P}$ and its components at different growth rates were examined as we supported the view held by Kashket $(1981 a)$ that 'it was important to examine the status of energy metabolism in the physiological condition of growth'.

According to the chemiosmotic theory the intracellular $\mathrm{pH}$ should be more alkaline than the extracellular $\mathrm{pH}$ resulting in a positive $\Delta \mathrm{pH}$ (i.e. inside alkaline). However, the cells used here were at low growth rates, and, consequently, high extracellular $\mathrm{pH}$ values. In order for these cells to maintain a positive $\Delta \mathrm{pH}$, the intracellular $\mathrm{pH}$ would have to be in the region of $8 \cdot 0$ to $9 \cdot 0$. At these postulated intracellular $\mathrm{pH}$ values, the functioning of intracellular enzymes would probably be severely retarded. Therefore, it appears that in $P$. aeruginosa the cytoplasm has the ability to buffer the intracellular $\mathrm{pH}$ around neutrality (Fig. 3) to optimize the function of these enzymes. This close regulation of the intracellular $\mathrm{pH}$ has been reported in various bacteria (Kashket, 1981 a, b; Kihara \& Macnab, 1981; Felle et al., 1980; Khan \& Macnab, 1980; Padan et al., 1976; Hsung \& Haug, 1975). Most of the previous research, where the $\Delta \mathrm{pH}$ is found to be 
positive, has dealt with cells removed from cultures at high growth rates (i.e. exponential phase cells) and it is probable that, if one extrapolated back the lines in Fig. 3, one would also find that in this organism a positive $\Delta \mathrm{pH}$ exists at higher growth rates.

The membrane potential $(\Delta \psi)$ was found to be unaffected by extracellular $\mathrm{pH}$ over the range examined (Fig. 2). Similar results were found for Escherichia coli (Padan et al., 1976; Kashket, 1981 b) and Staphylococcus aureus (Kashket, 1981 a). It was also found to be unaffected by growth rate over the range examined (Fig. 3) a result also supported by similar findings for $S$. aureus (Kashket, 1981 a) and $E$. coli (Murastugu et al., 1979). Thus as the $\Delta \psi$ remained constant, the $\Delta \mathbf{P}$ was dependent on the $\triangle \mathrm{pH}$.

It was evident that as the $\Delta \mathrm{P}$ decreased, exoprotease production increased (Fig. 7). It must be emphasized, however, that the presence of a negative $\Delta \mathrm{pH}$ (i.e. inside acidic) in this study was only at low growth rates. The $\Delta \mathrm{pH}$ was not determined at higher growth rates because no exoprotease was produced at these growth rates. It is postulated that the situation that prevails in cells of low growth rates (where exoprotease is produced) is that as the extracellular $\mathrm{pH}$ increases (above 7.0) the $\Delta \mathrm{pH}$ becomes negative due to the fact that the intracellular $\mathrm{pH}$ remains constant at approximately 7.0 at these extracellular $\mathrm{pH}$ values. However, the $\Delta \psi$ remains constant and cannot compensate further for the decrease in the $\Delta \mathrm{pH}$. Therefore, the $\Delta \mathrm{P}$ decreased. These results are supported by recent findings by other investigators using $S$. aureus (Kashket, 1981a), E. coli (Padan et al., 1976; Kashket, 1981b), Mycoplasma gallisepticum (Rottem et al., 1981), Bacillus subtilis (Shioi et al., 1980) when grown at high extracellular $\mathrm{pH}$ values. On the other hand, we postulate that, in $P$. aeruginosa cells at high growth rates, the $\Delta \mathrm{P}$ remains relatively constant but the relative contributions of the $\Delta \psi$ and the $\Delta \mathrm{pH}$ vary with varying extracellular $\mathrm{pH}$, and the findings of Shioi et al. (1980) for B. subtilis support this.

According to the chemiosmotic theory, the formation of a $\Delta \mathrm{P}$ is a result of the expulsion of protons from the respiratory chain and this $\Delta \mathrm{P}$ promotes the influx of protons back into the cell through the membrane-bound ATPase (Harold, 1972). However, the equilibrium of the ATPase is very delicately poised and the presence of a $\Delta \mathbf{P}$ shifts the equilibrium towards ATP formation. When the $\Delta P$ decreased the equilibrium shifts and the ATPase breaks down ATP due to the net flowing out of protons through the ATPase. Therefore, as the $\triangle \mathrm{P}$ decreases so too does the ATP concentration of the cell which suggests a possible role for ATP in the regulation of exoprotease production.

Results presented in this paper also indicated a possible physiological explanation behind the fact that micro-organisms have $\mathrm{pH}$ optima for product formation that do not always correspond to their $\mathrm{pH}$ optimum for growth, and, emphasizes the importance of $\mathrm{pH}$ control in product formation.

\section{REFERENCES}

Collins, S. H. \& Hamilton, W. A. (1.976). Magnitude of the protonmotive force in respiring Staphylococcus aureus and Escherichia coli. Journal of Bacteriology 126, 1224-1231.

Dills, S. S., Apperson, A., Schmidt, M. R. \& Saier, M. H. (1980). Carbohydrate transport in bacteria. Microbiological Review's 44, 385-418.

Felle, H., Porter, J. S., Slayman, C. L. \& Kaback, H. R. (1980). Quantitative measurements of membrane potential in Escherichia coli. Biochemistry 19, $3585-3590$.

Gollbourne, E. A. \& Greenberg, E. P. (1980). Relationship between protonmotive force and motility in Spirochaeta aurantia. Journal of Bacteriology 143, 1450-1457.

HaROLD, F. M. (1972). Conservation and transformation of energy by bacterial membranes. Bacteriological Reviews 36, 172-230.

HaROLD, F. M. (1974). Chemiosmotic interpretation of active transport in bacteria. Annals of the New York Academy of Sciences 227, 297-311.

Harold, F. M., Pavlasova, E. \& BaArda, J. R. (1970). A transmembrane $\mathrm{pH}$ gradient in Streptococcus faecalis: origin and dissipation by proton conductors and $N, N^{\prime}$-dicyclohexylcarbodiimide. Biochimica et biophysica acta 196, 235-244.

Hsung, J. C. \& Haug, A. (1975). Intracellular pH of Thermoplasma acidophila. Biochimica et biophysica acta 389, 477-482.

KASHKeT, E. R. (1981a). Protonmotive force in growing Streptococcus lactis and Staphylococcus aureus cells under aerobic and anaerobic conditions. Journal of Bacteriology 146, 369-376.

KASHKeT, E. R. $(1981 b)$. Effects of aerobiosis and nitrogen source on the protonmotive force in growing Escherichia coli and Klebsiella pneumoniae cells. Journal of Bacteriology 146, 377-384.

KASHKeT, E. R. \& Wong, P. T. S. (1969). The 
intracellular pH of Escherichia coli. Biochimica et biophysica acta 193, 212-214.

Khan, S. \& MaCNaB, R. M. (1980). Proton chemical potential, proton electrical potential and bacterial motility. Journal of Molecular Biology 138, 599-614.

KiHARA, M. \& MACNAB, R. M. (1981). Cytoplasmic pH mediates $\mathrm{pH}$ taxis and weak-acid repellent taxis of bacteria.' Journal of Bacteriology 145, '12091221 .

MALONEY, P. C. (1977). Obligatory coupling between proton entry and the synthesis of adenosine $5^{\prime}$ triphosphate in Streptococcus lactis. Journal of Bacteriology 132, 564-575.

Maloney, P. C., Kashket, E. R. \& Wilson, T. H. (1975). Methods for studying transport in bacteria. In Methods in Membrane Biology, vol. 5, pp. 1-59. Edited by E. D. Korn. New York \& London: Plenum Press.

Murastugu, M., Kamo, N., Kobatake, Y. \& KimURA, K. (1979). Determination of membrane potential of Escherichia coli with use of an electrode sensitive to tetraphenyl phosphonium. Journal of Electroanalytical Chemistry (Bioelectrochemistry and Bioenergetics 6) 104, 477-491.

Padan, E., Zilberstein, D. \& Rottenberg, H. (1976). The proton electrochemical gradient in Escherichia coli cells. European Journal of Biochemistry 63, 533-541.

RotTem, S., LinkeR, C. \& Wilson, T. H. (1981). Protonmotive force across the membrane of $\mathrm{Myco}$ plasma gallisepticum and its possible role in cell volume regulation. Journal of Bacteriology 145, 1299 1309.
RoTtenberg, H. (1975). The measurement of transmembrane electrochemical proton gradients. Bioenergetics 7, 61-74.

RotTenberG, H., Grunwald, T. \& Avron, M. (1972). Determination of $\Delta \mathrm{pH}$ in chloroplasts. I. Distribution of $\left[{ }^{14} \mathrm{C}\right]$ methylamine. European Journal of Biochemistry 25, 54-63.

ShioI, J., MasuUra, S. \& Imar, Y. (1980). Quantitative measurements of protonmotive force and motility in Bacillus subtilis. Journal of Bacteriology 144, 891-897.

SPIZIZEN, J. (1957). Infection of protoplasts by disrupted T2 virus. Proceedings of the National Academy of Sciences of the United States of America 43, 694-701.

Stanier, R. Y., Palleroni, N. J. \& Doudoroff, M. (1966). The aerobic pseudomonads: a taxonomic study. Journal of General Microbiology 43, 159-271.

Tsuchiya, T. (1977). Adenosine 5'-triphosphate synthesis driven by a protonmotive force in membrane vesicles of Escherichia coli. Journal of Bacteriology 129, 763-769.

Whooley, M. A., O'Callaghan, J. A. \& McloughLIN, A. J. (1983). The effect of substrate on the regulation of exoprotease production by Pseudomonas aeruginosa ATCC 10145. Journal of General Microbiology 129, 981-988.

WIERSMA, M. (1978). Regulation of extracellular proteolytic enzyme synthesis in Vibrio SAI. Ph.D. thesis, University of Groningen, Holland.

Wilson, D. M., Alderete, J. F., Maloney, P. C. \& WiLSON, T. H. (1976). Protonmotive force as the source of energy for adenosine 5'-triphosphate synthesis in Escherichia coli. Journal of Bacteriology 126, 327-337. 